\title{
OPTIMIZATION OF LEVOFLOXACIN REMOVAL FROM AQUEOUS SOLUTION USING ELECTROCOAGULATION PROCESS BY RESPONSE SURFACE METHODOLOGY
}

\section{S. J. Mohammed}

Researcher

Coll. of Eng.-University of Baghdad eng.sabah1212@gmail.com
M. J. Mohammed-Ridha Assist. Prof.

Coll. of Eng.-University of Baghdad muhannadenviro@coeng.uobaghdad.edu.iq

\section{ABSTRACT}

This study was aimed to investigate the response surface methodology (RSM) to evaluate the effects of various experimental conditions on the removal of levofloxacin (LVX) from the aqueous solution by means of electrocoagulation (EC) technique with stainless steel electrodes. The EC process was achieved successfully with the efficiency of LVX removal of $90 \%$. The results obtained from the regression analysis, showed that the data of experiential are better fitted to the polynomial model of second-order with the predicted correlation coefficient (pred. $R^{2}$ ) of $\mathbf{0 . 7 2 3}$, adjusted correlation coefficient (Adj. $R^{2}$ ) of 0.907 and correlation coefficient values $\left(R^{2}\right)$ of 0.952 . This shows that the predicted models and experimental values are in good agreement. The results of the kinetic study showed that the second-order kinetic model was in good agreement with the experimental results and suggested that the mechanism of chemisorption controlled the LVX adsorption. The experimental results indicated that the adsorption of LVX on iron hydroxide flocs follows Sips isotherm with the value of the correlation coefficient $\left(R^{2}\right)$ of 0.937 . Sips isotherm shows that both homogenous and heterogeneous adsorption can be occurred.

Keywords: pharmaceuticals, wastewater treatment, stainless steel electrodes, kinetic, isotherm

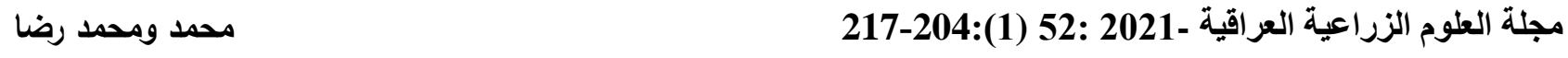

$$
\begin{aligned}
& \text { الازالة المثلى لليفوفلوكساسين من المحاليل المائية بطريقة التكتل الكهريائي باستخدام منهجية سطح الاستجابة } \\
& \text { مهند جاسم محمدرضا } \\
& \text { استاذ مساعد } \\
& \text { جامعة بغداد -كلية الهندسة } \\
& \text { صباح جرجيس محمد } \\
& \text { باحث } \\
& \text { جامعة بغداد-كلية الهندسة }
\end{aligned}
$$

الكلمات المفتاحية: المستحضرات الصيدلانيه، معالجة مياه الصرف الصحي، اقطاب الفولاذ المقاوم للصدأ، الحركية، الايسوثرم 


\section{INTRODUCTION}

The application of fertilizers, pesticides and herbicides for increasing agricultural production lead to major problems: pollution of water resources allotted to agriculture in addition to increasing groundwater pollution, which seemingly stems from activities of agricultural (5). One must take into account the availability of good management to the water (16). Rivers are the most significant natural sources for human life, but it is being contaminated with industrial wastewater, sewage, and other activities of human (3). In addition, the quality of water is affected by nature, such as climate, hydrological and geological, as well as different anthropogenic such as industrial sewage water, municipal discharge and agriculture drainage (1). Although many benefits of pharmaceuticals and higher consumption of human and veterinary medicine may cause the release of wastewater containing compounds of pharmaceuticals from different sources, the release of the accumulated materials and residues, especially antibiotics and their metabolites in water sources. This is a major challenge to the environment and public health (29). Even at low concentrations, pharmaceutical compounds can cause serious environmental damage. These compounds, particularly the antibiotics, affect the quality of soil, surface water, and groundwater. It is necessary to improve certain efficient and cost-effective treatment techniques to remove these contaminants (38). Antibiotics are the greatest pharmaceutical contaminants notice in the aquatic environment (24). Various categories of antibiotics were detected in water sources such as surface water and groundwater, as well as in some conditions in drinking water (24). Fluoroquinolones $\left(\mathrm{FQ}_{\mathrm{S}}\right)$ is a group of antibiotics pharmaceuticals, which are used generally in the handling of both diseases affecting humans and animals. FQs constitute one of the greatest main groups of antibiotics worldwide depending on annual global sales(17). The annual consumption of FQs was indicated to be more than $44,000,000$ tons worldwide due to use against bacterial diseases (18). Because metabolized $\mathrm{FQ}_{\mathrm{S}}$ are incomplete through therapy human or animal, it is discharged from $20-80 \%$ of these compounds in wastewater(34). Studies indicate that the continuous introduction of these contaminants with their metabolites in wastewater and the inefficiency of several traditional sewage treatment plants in their removal may pose possible health risks to humans through drinking water and the food chain (21). Levofloxacin (LVX) is an antibiotic belong to the third generation quinolones. The LVX is consumed widespread and the absence of treatment processes that target these contaminants causing in their diffusion in the aquatic environment(14). LEV is resistant to degradation and typically escapes from traditional wastewater treatment plants. Consequently, a permanent appearance of LEV in wastewater may lead to toxicity and bioaccumulation in the aquatic environment (15). As a result, it was necessary to improve an effective method to remove LEV from wastewater. There are many techniques applied to the removal of antibiotics from wastewater such as ion exchange (33), liquid membrane (2), photo electrocatalytic degradation (22), ozonation (19), photo-Fenton process (8) and adsorption(30). Among these techniques presented, Adsorption is an effective technique used widely to treat low antibiotic concentration. In recent times, antibiotic absorption on absorbent materials depending on metal oxides such as hydroxides of iron and aluminum(9, 31), montmorillonite (6) were reported. This study suggests the electrocoagulation (EC) process to remove LEV from water, which was chosen due to its widespread use, high water solubility, high remaining toxicity and lack of biodegradability. Recently a study has shown that the EC provides an alternative method attractive for water treatment. Aluminum or iron is usually used as an electrode in the electrocoagulation process. The electrocoagulation process is described by easy and simple operated equipment, short process time, low sludge production and no addition of chemicals (32). The main objective of this study is to study the features of the electrocoagulation technique and its effectiveness in the removal of levofloxacin (LVX) from aqueous solutions. The experiment design and response surface methodology (RSM) have been used to 
improve the operational conditions of the electrocoagulation to remove LVX.

\section{MATERIALS AND METHODS}

\section{Chemicals}

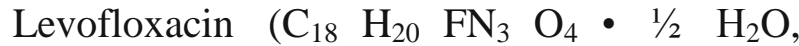
molecular weight $370.38 \mathrm{~g} / \mathrm{mol}$ ) was bought from Julphar Gulf Pharmaceutical Industries. Sodium chloride $(\mathrm{NaCl})$ was used to increase conductivity in the solution. In addition, such as $\mathrm{HCl}$ and $\mathrm{NaOH}$ was used to adjust the $\mathrm{pH}$. Distilled water was used in all experiments solutions. Electrodes used in the experiments made of stainless steel material.

\section{Experimental setup and procedure}

The EC tests were done with $1000 \mathrm{ml}$ of samples in a cylindrical glass cell. The EC processes generally carried out in an electrochemical reactor consisted of an electrolytic cell containing a pair of electrodes: the anode and cathode. The EC experiments were done using stainless steel electrodes with dimensions of $2 \mathrm{~mm}$ thickness and $8.5 \mathrm{~cm}$ in diameter. It was placed in the electrolytic cell immersed horizontally in the wastewater to be treated and connected to an external power source (digital direct current power supply DC) with voltage in the range of $0-30 \mathrm{~V}$ and current in the range of $0-5 \mathrm{~A}$. The solution was agitated mechanically by a magnetic stirrer (Isolab, Germany) at a speed of $120 \mathrm{rpm}$ through runtime. The electrocoagulation reactor used in experiments is shown in Fig. 1.

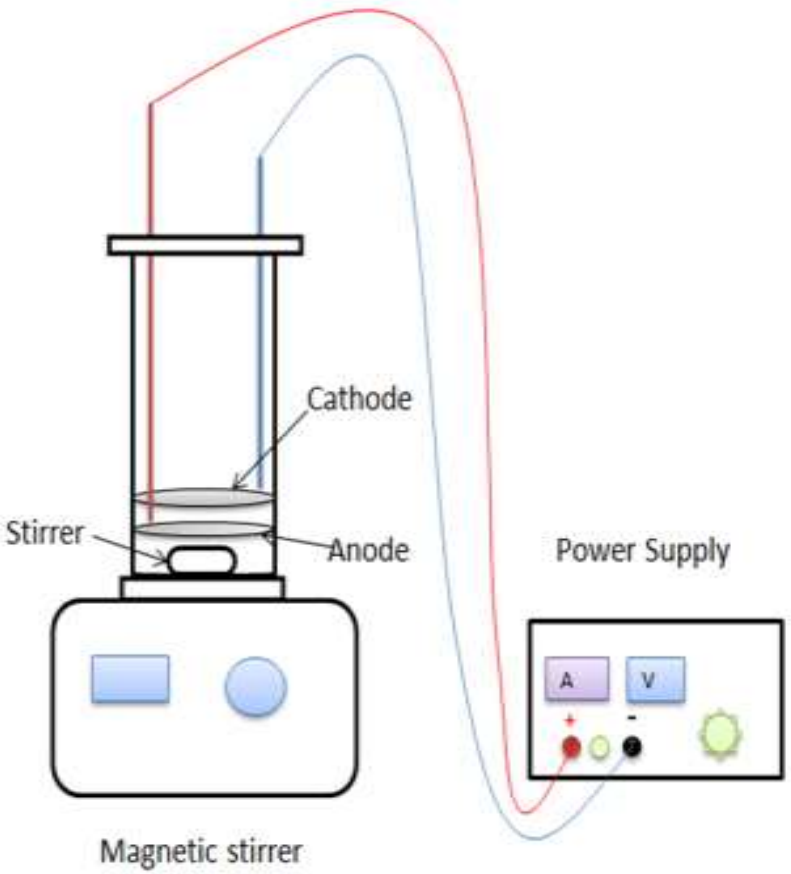

Fig. 1. schematic diagram for the experimental electrocoagulation apparatus
To prepare the electrodes for each experiment they should be washed first with a $0.2 \mathrm{M}$ solution of hydrochloric acid for 2 min and rinse with distilled water and then dried. After each experiment, the same process was applied. The $\mathrm{pH}$ of the solution was adjusted by adding $0.01 \mathrm{~N}$ of $\mathrm{NaOH}$ or $0.01 \mathrm{~N}$ of $\mathrm{HCl}$ before each experiment and measured by $\mathrm{pH}$ meter (WTW, inoLab 720, Germany) laboratory. All experiments were carried out in the batch system. The sample was taken from the EC cell at the end of the runtime and the suspended materials were then allowed to be stable for 30 minutes. The wastewater samples treated were passed through a $0.45 \mu \mathrm{m}$ pore size membrane (Whatman, Germany) and then analyzed with a UV-Vis spectrophotometer (Shimadzu UV -1800, Japan) at a wavelength of $293 \mathrm{~nm}$ was utilized to determine the amount of LVX remaining. The concentration of LVX was measured from the calibration curve that plotted against absorbance and concentration. The removal efficiency of the levofloxacin was estimated by measuring the concentration before and after the process, according to the following equation:

Removal LVX $=\frac{\mathrm{C}_{\mathbf{o}}-\mathrm{C}_{\mathbf{t}}}{\mathrm{C}_{\mathrm{o}}} \mathbf{1 0 0 \%}$

Where $\mathrm{C}_{\mathrm{o}}$ is the initial concentration of LVX $(\mathrm{mg} / \mathrm{l}) ; \mathrm{C}_{\mathrm{t}}$ is the concentration at any time of $\operatorname{LVX}(\mathrm{mg} / \mathrm{l})$

\section{Statistical design}

In the present study, central composite design (CCD) was employed to improve the efficiency of LVX removal by means of improving the operational conditions using response surface methodology. Response surface methodology (RSM) was generally applied to optimize experimental conditions. However, the RSM consists of a group of mathematical and statistical techniques for optimizing the process factors and building quadratic models providing the statistical relationship between the variables. The purpose of RSM is to select the optimal experimental conditions of the system or to select which area meets the operating specifications. The CCD was applied to evaluate 4 selected parameters (A: initial LVX concentration, B: $\mathrm{pH}, \mathrm{C}$ : current density, D: time of electrolysis) on the efficiency of LVX removal and optimizing the operating conditions of the treatment process in 
electrocoagulation process. The removal efficiency of the levofloxacin was fitted to an overall function indicating the reaction between independent and dependent variables by means of the second-order polynomial equation. Experiential data from the CCD was examined and fitted to a model of the secondorder polynomial which can be represented as below:

$$
\begin{gathered}
Y=\beta_{0}+\sum_{i=1}^{n} \beta_{i} X_{i}+\sum_{i=1}^{n} \beta_{i i} X_{i}^{2}+ \\
\sum_{i=1}^{n-1} \sum_{j=i+1}^{n} \beta_{i j} X_{i} X_{j}
\end{gathered}
$$

Where $\mathrm{Y}$ is the denote of the expected response to remove LVX, $\beta_{0}$ is the intercept parameter, $\beta_{\mathrm{i}}$ is the linear coefficients, $\beta_{\mathrm{ii}}$ is the quadratic coefficients, $\beta_{\mathrm{ij}}$ is the interaction coefficients, $X_{i}$ and $X_{j}$ are the coded values of independent factors $(4,7,36)$. Various ranges for each parameter were examined to control the effect of determined parameters on the efficiency of the process to remove LVX. The selection of operating ranges for each parameter can be shown in Table 1 .

\begin{tabular}{|c|c|c|c|}
\hline Co $(\mathrm{mg} / \mathrm{L})$ & $\mathrm{CD}\left(\mathrm{mA} / \mathrm{cm}^{2}\right)$ & pH & $t(\min )$ \\
\hline$(-1) \quad(+1)$ & $(-1) \quad(+1)$ & $(+1)$ & $(-1) \quad(+1)$ \\
\hline 100 & 20 & 3 & 60 \\
\hline
\end{tabular}

Table 1. Operating ranges for each parameter in the electrocoagulation process

Co: the initial concentration of LVX, CD: The current density, t: time of electrolysis. DesignExpert version 10.0.2.0 was used for the experimental parameters design and statistical analysis of data in the EC process. The verification of the accuracy value of the adequacy of the model was developed using an analysis of variance (ANOVA).

\section{RESULTS AND DISCUSSION}

Preliminary assessment of the EC process

Effect of the conductivity: Solution conductivity is an important factor for electrochemical processes. Salt $(\mathrm{NaCl})$ is typically used to increase the conductivity of the wastewater to be treated. It should be noted that the conductivity of wastewater affects the efficiency of removal, cell voltage and energy consumption in the process of electrocoagulation. Furthermore, increasing wastewater conductivity to be treated in the process of $\mathrm{EC}$ using $\mathrm{NaCl}$ has other advantages, for example, chloride ions could largely reduce the adverse impacts of other anions, such as $\mathrm{SO}_{4}{ }^{2-}$ and $\mathrm{HCO}_{3}{ }^{-}$. The existence of $\mathrm{CO}_{3}{ }^{2-}$ anions leads to precipitation of $\mathrm{Ca}^{2+}$ cations which forms an insulating layer on the cathode surface (Eqs. (3) and (4)) and leads to growing the ohmic resistance of the electrochemical cell (12).

$$
\begin{array}{ll}
\mathrm{HCO}_{3}{ }^{-}+\mathrm{OH}^{-} & \mathrm{CO}_{3}{ }^{2-}+\mathrm{H}_{2} \mathrm{O} \\
\mathrm{Ca}^{2+}+\mathrm{CO}_{3}^{2-} \longrightarrow \mathrm{CaCO}_{3}
\end{array}
$$

In this study, preliminary studies have been conducted to evaluate the effect of the concentration of salt $(\mathrm{NaCl})$ to remove LVX using electrodes stainless steel. As shown in Fig. 2, LVX removal was increased from 64 to $80 \%$ by increasing $\mathrm{NaCl}$ concentration from 200 to $600 \mathrm{mg} / \mathrm{L}$. This was due to the increase in the concentration of $\mathrm{NaCI}$ which led to increase the conductivity of the solutions and as a result, the improve efficiency of LVX removal. 


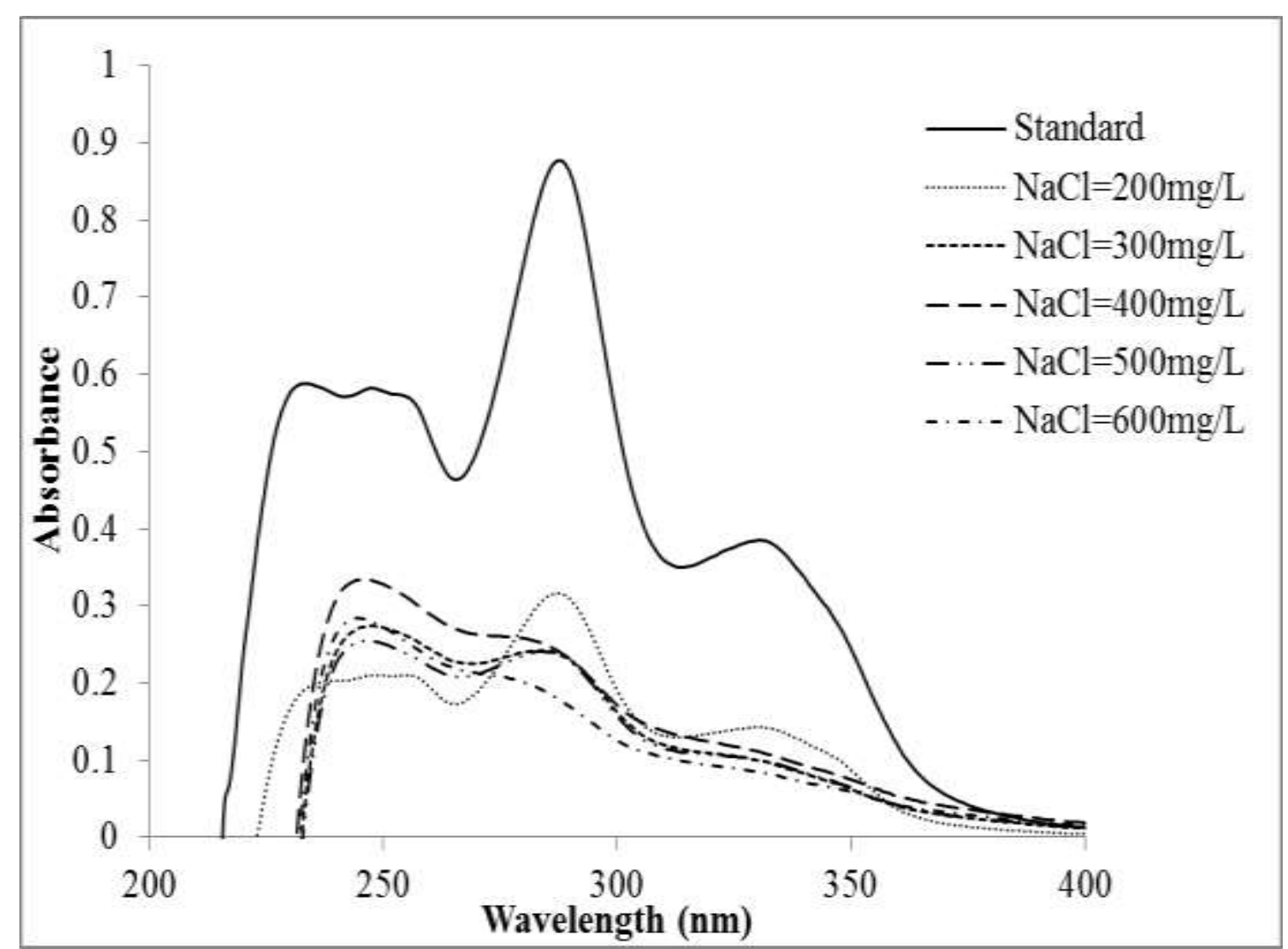

Fig. 2. Effect of the conductivity on the efficiency of LVX removal (Experimental conditions: initial concentration $=10 \mathrm{mg} / \mathrm{L}, \mathrm{pH}=4$, inter-electrode distance $=1.5 \mathrm{~cm}$, time of electrolysis $=30$ min, current density $=20 \mathrm{~mA} \cdot \mathrm{cm}^{-2}$ )

\section{Effect of distance between the electrodes}

The distance between the electrodes plays an important role in the electrochemical processes as the electrostatic field depends on the spacing between the cathode and the anode. The decline in the ohmic possibility of the electrocoagulation cell is proportional to the inter-electrode distance and furthermore, the spacing between electrodes influences the electrolysis power consumption particularly when wastewater conductivity is low (20). To study the effect of distance between the electrodes on the removal efficiency of the LVX, the distance between electrodes was changed in the range of 0.5 to $3.0 \mathrm{~cm}$ and other experimental conditions remained constant. As shown in Fig. 3, at the minimum spacing between electrodes, the LVX removal efficiency decreased from 80 to $77 \%$ when the spacing between electrodes decreased from 1.5 to $0.5 \mathrm{~cm}$. This is a result of the reality that the iron hydroxides produced in order to work as the flocs and remove the contaminant by means of precipitation degraded through collision with each other because of high electrostatic attraction(13). The contaminant removal efficiency increased by increasing the spacing between electrodes from the minimum until the optimal spacing. Because by increasing the spacing between electrodes, a reduction in electrostatic effects can be occurred that slow the movement of the ions generated. This provides additional time for the metal hydroxide generated to form flocs which leads to an increase in the removal efficiency of contaminants from the solution (20). The removal efficiency was decreased from 80 to $69 \%$ by increasing the distance between the electrodes from 1.5 to $3.0 \mathrm{~cm}$, because when the distance between the electrodes increases, the ion transmission path increases. This leads to a reduction in the electrostatic attraction which led to the formation of less than the quantity required flocs to remove contaminants (20). 


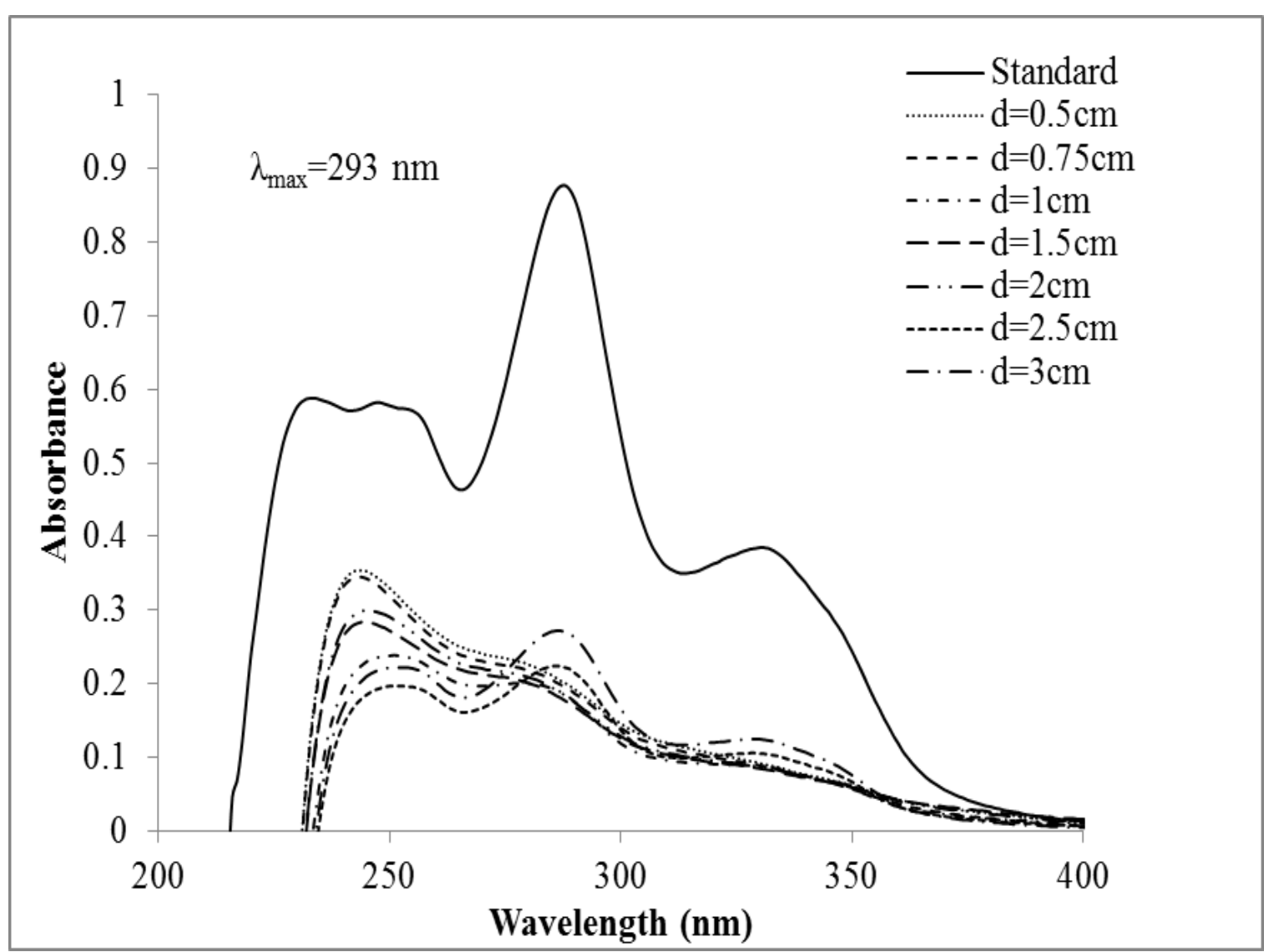

Fig. 3. Effect of inter-electrode distance on the efficiency of LVX removal (Experimental conditions: initial concentration $=10 \mathrm{mg} / \mathrm{L}, \mathrm{pH}=4$, time of electrolysis $=30 \mathrm{~min}$, current density $=20 \mathrm{~mA} . \mathrm{cm}^{-2}, \mathrm{NaCl}=500 \mathrm{~m} \mathrm{~g} / \mathrm{L}$ )

The experimental conditions are summarized along with the results obtained from 30 experiments according to the design of the response surface methodology (RSM) in Table 2. As shown in Table 2, the removal efficiency of LVX was changed from $50 \%$ to $90 \%$.

Fitting of the model and statistical analysis Thirty experiments designed by RSM were conducted to evaluate the simple and combined effects of the four main parameters including, initial $\mathrm{pH}$ of the solution, initial LVX concentration, time of electrolysis and current density on the efficiency of LVX removal and optimizing the operating conditions of the EC process. The obtained results were fitted to the model of quadratic in order to determine a mathematical relationship between the applied factors and the observed response. The developed RSM model equation is expressed as below:=

$$
\text { Removal }(\%)=106.077+0.912 A-
$$
$21.113 B-0.473 C+0.523 D-$ $0.054 A B-0.02 A C-2.4 \times 10^{-4} A D+$ $0.184 B C-0.043 B D+0.016 C D-$ $0.004 A^{2}+1.483 B^{2}+0.016 C^{2}-3.78 \times$ $10^{-3} D^{2}$

Where A: initial LVX concentration, B: initial $\mathrm{pH}$ of the solution, $\mathrm{C}$ : current density, $\mathrm{D}$ : time of electrolysis. The suitability of the model was verified and summarized the experimental results obtained in Table 3 
Table 2. Experimental conditions of four parameters in the CCD matrix and results of LVX removal obtained in the experiments

\begin{tabular}{|c|c|c|c|c|c|c|c|}
\hline \multirow[t]{2}{*}{ Run } & \multicolumn{4}{|c|}{ Actual values } & \multirow{2}{*}{$\begin{array}{l}\text { Removal (\%) } \\
\text { (experimental) }\end{array}$} & \multirow{2}{*}{$\begin{array}{l}\text { Removal (\%) } \\
\text { (predict) }\end{array}$} & \multirow[t]{2}{*}{ Error } \\
\hline & $\mathrm{C}_{0}\left(\mathrm{mg} . \mathrm{L}^{-1}\right)$ & pH & $\mathrm{CD}\left(\mathrm{mA} \cdot \mathrm{cm}^{-2}\right)$ & $\begin{array}{l}\text { Time } \\
\text { (min) }\end{array}$ & & & \\
\hline 1 & 52.5 & 5 & 12.5 & 5 & 53 & $\mathbf{5 7 . 5 5}$ & 4.55 \\
\hline 2 & 80.13 & 6.16 & 16.9 & 16.5 & 51 & 49.15 & -1.9 \\
\hline 3 & 24.87 & 6.16 & 8.14 & 16.5 & 50 & 51.59 & 1.59 \\
\hline 4 & 24.87 & 3.84 & 8.14 & 48.5 & 71.85 & 75.11 & 3.26 \\
\hline 5 & 52.5 & 5 & 12.5 & 32.5 & 66 & 67.2 & 1.2 \\
\hline 6 & 24.87 & 6.16 & 8.14 & 48.5 & 53.75 & 55.86 & 2.11 \\
\hline 7 & 52.5 & 5 & 20 & 32.5 & 69.6 & 70.35 & 0.75 \\
\hline 8 & 80.13 & 3.84 & 8.14 & 48.5 & 80 & 81.81 & 1.81 \\
\hline 9 & 80.13 & 6.16 & 8.14 & 48.5 & $\mathbf{5 7 . 3 7}$ & 55.61 & -1.8 \\
\hline 10 & 80.13 & 3.84 & 8.14 & 16.5 & 73.82 & 74.76 & 0.94 \\
\hline 11 & 52.5 & 5 & 12.5 & 60 & 75.8 & 71.12 & -4.7 \\
\hline 12 & 80.13 & 6.16 & 8.14 & 16.5 & 52.85 & 51.76 & -1.1 \\
\hline 13 & 24.87 & 3.84 & 16.9 & 48.5 & 82 & 82.96 & 0.96 \\
\hline 14 & 52.5 & 5 & 12.5 & 32.5 & 67 & 67.2 & 0.2 \\
\hline 15 & 52.5 & 5 & 12.5 & 32.5 & 67.49 & 67.2 & -0.3 \\
\hline 16 & 24.87 & 6.16 & 16.9 & 48.5 & 67 & 67.36 & 0.36 \\
\hline 17 & 24.87 & 3.84 & 16.9 & 16.5 & 68 & 71.02 & 3.02 \\
\hline 18 & 80.13 & 3.84 & 16.9 & 48.5 & 80 & 80.01 & 0.01 \\
\hline 19 & 52.5 & 5 & 5 & 32.5 & 66.77 & 65.85 & -0.9 \\
\hline 20 & 52.5 & 5 & 12.5 & 32.5 & 67.5 & 67.2 & -0.3 \\
\hline 21 & 5 & 5 & 12.5 & 32.5 & 62 & 59.64 & -2.4 \\
\hline 22 & 52.5 & 5 & 12.5 & 32.5 & 66.5 & 67.2 & 0.7 \\
\hline 23 & 80.13 & 6.16 & 16.9 & 48.5 & 53 & 57.46 & 4.46 \\
\hline 24 & 52.5 & 3 & 12.5 & 32.5 & 90 & 89.7 & -0.3 \\
\hline 25 & 24.87 & 3.84 & 8.14 & 16.5 & 72 & 67.64 & -4.4 \\
\hline 26 & 52.5 & 5 & 12.5 & 32.5 & 67 & 67.2 & 0.2 \\
\hline 27 & 52.5 & 7 & 12.5 & 32.5 & 56.38 & 56.53 & 0.15 \\
\hline 28 & 80.13 & 3.84 & 16.9 & 16.5 & 70.64 & 68.49 & -2.2 \\
\hline 29 & 24.87 & 6.16 & 16.9 & 16.5 & 60.75 & 58.62 & -2.1 \\
\hline 30 & 100 & 5 & 12.5 & 32.5 & 55 & 57.25 & 2.25 \\
\hline
\end{tabular}

Table 3. ANOVA results for response surface of quadratic model

\begin{tabular}{|c|c|c|c|c|c|c|}
\hline \multirow{2}{*}{ Response } & \multirow{2}{*}{ Source } & \multicolumn{5}{|c|}{ Analysis of variance } \\
\hline & & $\begin{array}{l}\text { Sum of } \\
\text { square }\end{array}$ & $\begin{array}{l}\text { degree } \\
\text { freedom }\end{array}$ & $\begin{array}{l}\text { Mean } \\
\text { square }\end{array}$ & F-value & $\begin{array}{l}\text { P-value } \\
\text { Prob>F }\end{array}$ \\
\hline \multirow{4}{*}{$\begin{array}{l}\text { LVX } \\
\text { removal } \\
(\%)\end{array}$} & Model & 2830.35 & 14 & 202.17 & 21.31 & $<0.0001$ \\
\hline & Residual & 142.29 & 15 & 9.49 & - & - \\
\hline & Lack of Fit & 140.56 & 10 & 14.06 & 40.55 & 0.0004 \\
\hline & Pure Error & 1.73 & 5 & 0.35 & - & - \\
\hline
\end{tabular}

According to obtained results in Table 3, the second-order with the predicted correlation ANOVA analysis indicates that the model of quadratic was significant with a confidence level of $95 \%$ and F-value of 21.31. The observed P-value probability was less than 0.05 indicate model terms are significant. According to the results obtained from the regression analysis, the data of experiential are better fitted to the polynomial model of coefficient (pred. $\mathrm{R}^{2}$ ) of 0.7235 , adjusted correlation coefficient (Adj. $\mathrm{R}^{2}$ ) of 0.9075 and correlation coefficient values $\left(\mathrm{R}^{2}\right)$ of 0.9521 . The difference between the value of Adjusted $\mathrm{R}^{2}$ and Predicted $\mathrm{R}^{2}$ is less than 0.2 , this shows that the predicted models and experimental values are in good agreement. Additionally, the amount of 18.68 for adequate precision is 
greater than 4 which shows an adequate indicator to noise ratio.

\section{Effect of parameters}

\section{Effect of initial concentration}

Mass transfer of solutes between solid and aqueous phase is depends on the initial concentration, which gives a great driving force to overcome all resistance of solutes (38). The results of the study revealed that the increase in the initial concentration of the LVX pollutants led to a decline in the removal efficiency of LVX. As shown in Fig. 4, at the center point of important working parameters mentioned, including $42 \mathrm{~min}$ reaction time, $3.84 \mathrm{pH}$ and $16.27 \mathrm{~mA} . \mathrm{cm}^{-2}$ current density, the removal efficiency of LVX increasing from $60 \%$ to $80 \%$ by decreasing its concentration from 80.13 to $24.86 \mathrm{mg} . \mathrm{L}^{-1}$. This is because of the fact that the amount of iron hydroxide flocs produced may not be enough to adsorption for the greater amount of contaminant particles at higher initial LVX concentrations. According to the law of Faraday, the metal hydroxide flocs formed during a certain period of time stay constant for different concentrations of LVX at a constant current density. However, the metal hydroxide flocs requirements are more important to concentration high LVX, and as a result, the amount of flocs becomes not enough to capture the quantities additional of LVX (4).

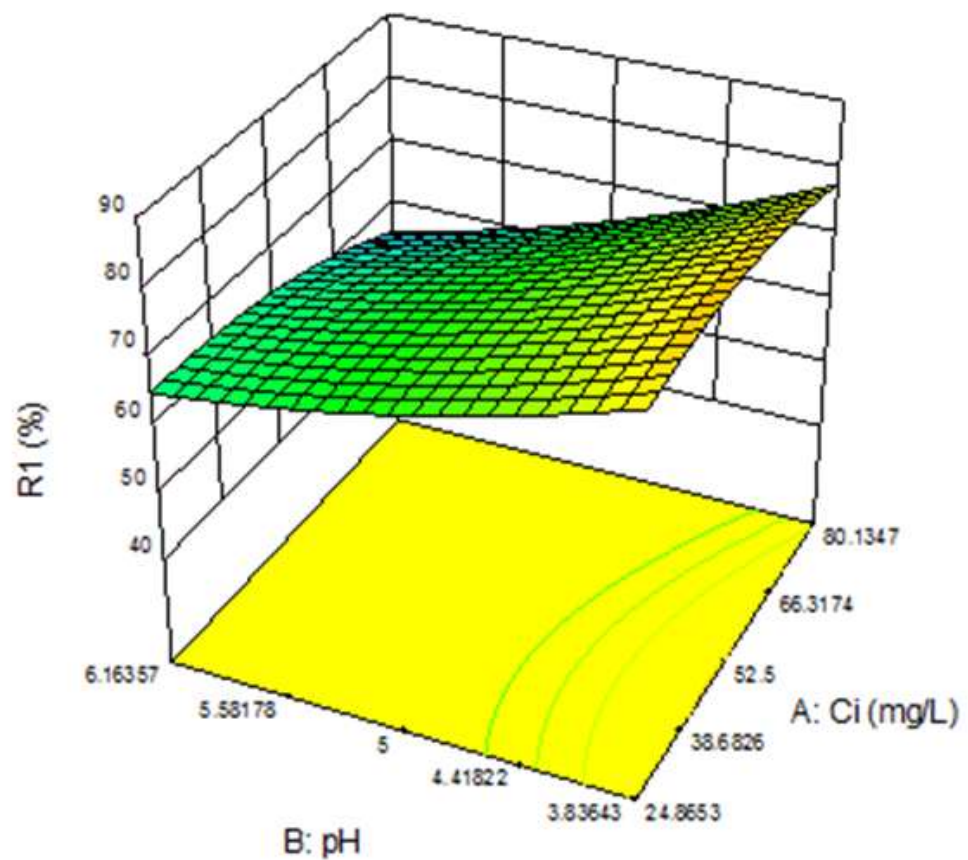

Fig. 4. Effect of initial $L V X$ concentration on the efficiency of $L V X$ removal

Effect of pH: The value of $\mathrm{pH}$ has been proven to be one of the important parameters affecting the effectiveness of the electrochemical processes, especially on the efficiency of the EC process (28). To study this effect, the initial $\mathrm{pH}$ value of the solution was taken within a range of 3 to 9 . The solution of LVX was adjusted to the required $\mathrm{pH}$ for each run by adding certain concentrations of sodium hydroxide. The effect of the $\mathrm{pH}$ value on the efficiency of LVX removal during the electrocoagulation process was illustrated in Fig. 5. The results obtained showed that decreasing the $\mathrm{pH}$ of the solution led to improve the efficiency of removing of pollutants and the optimum efficiency of removal was noticed at a $\mathrm{pH}$ value of 3.84. The efficiency of LVX removal decreases by either reducing or increasing the $\mathrm{pH}$ in the solution from the optimal $\mathrm{pH}$. The results obtained revealed that at high value of $\mathrm{pH}$ conditions, metal hydroxide which is the hydrolysis products of $\mathrm{Fe}^{3+}$ are soluble, and thus they are not able to absorb contaminants. $\left[\mathrm{Fe}(\mathrm{OH})_{2}\right]^{+}$and $\mathrm{Fe}(\mathrm{OH})_{3}$ are the leading type of hydrolysis reactions(25). 


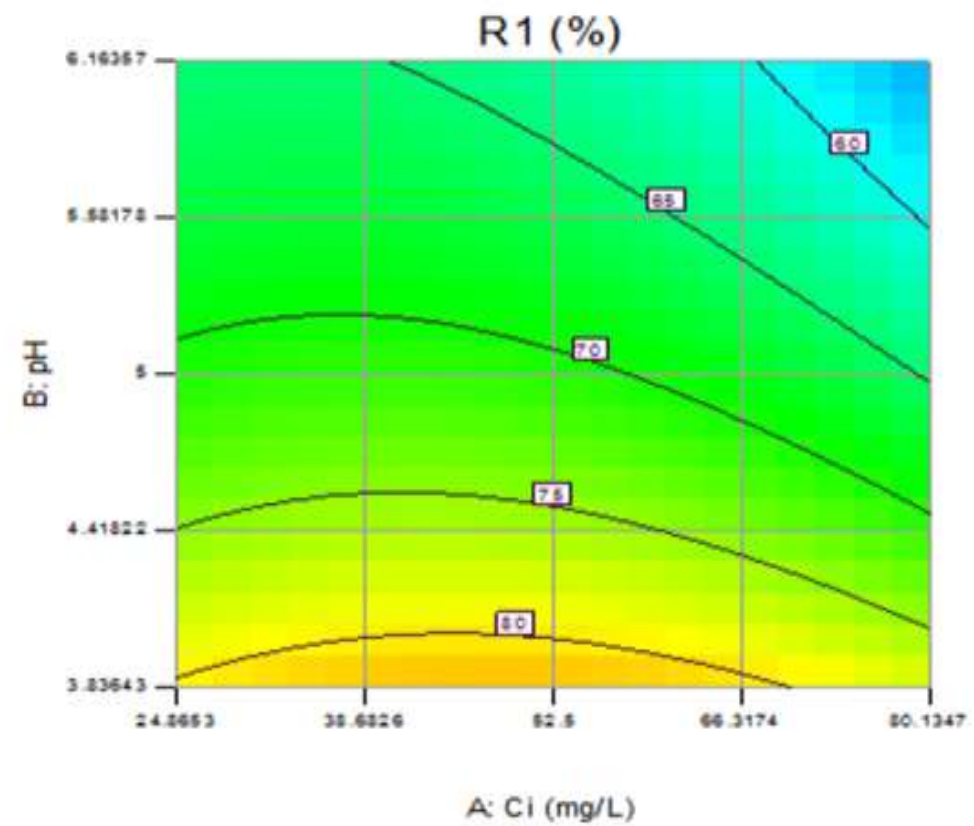

Fig. 5. Effect of $\mathrm{pH}$ on the efficiency of $\mathrm{LVX}$ removal

\section{Effect of the current density}

The current density (CD) is a significant factor to control the rate of reaction within the reactor, in all electrochemical processes. It is known that the $\mathrm{CD}$ controls the rate of bubble generation and the production rate of coagulant which influences the growth of flocs (23). To study the influence of current density on the removal efficiency of LVX, the EC process was conducted using different current densities from 5 to $20 \mathrm{~mA} \cdot \mathrm{cm}^{-2}$. According to the results presented in Fig.6, the efficiency of LVX removal was increased from $76 \%$ to $82 \%$ by increasing the current density from 8.136 to
$16.86 \mathrm{~mA} . \mathrm{cm}^{-2}$ at the center point of important working parameters mentioned, including 3.84 $\mathrm{pH}, 42 \mathrm{~min}$ reaction time and $42.79 \mathrm{mg} . \mathrm{L}^{-1}$ LVX concentrations. The current density showed a strong impact on the electrocoagulation process, particularly on shortened treatment time and the kinetics of removal. Increase the current density impacts the anodic dissolution amount and this gives a more amount of precipitate to remove contaminants. Furthermore, the rate of bubble produced increases with an increase in the current density that is useful to remove contaminants through $\mathrm{H}_{2}$ flotation (7).

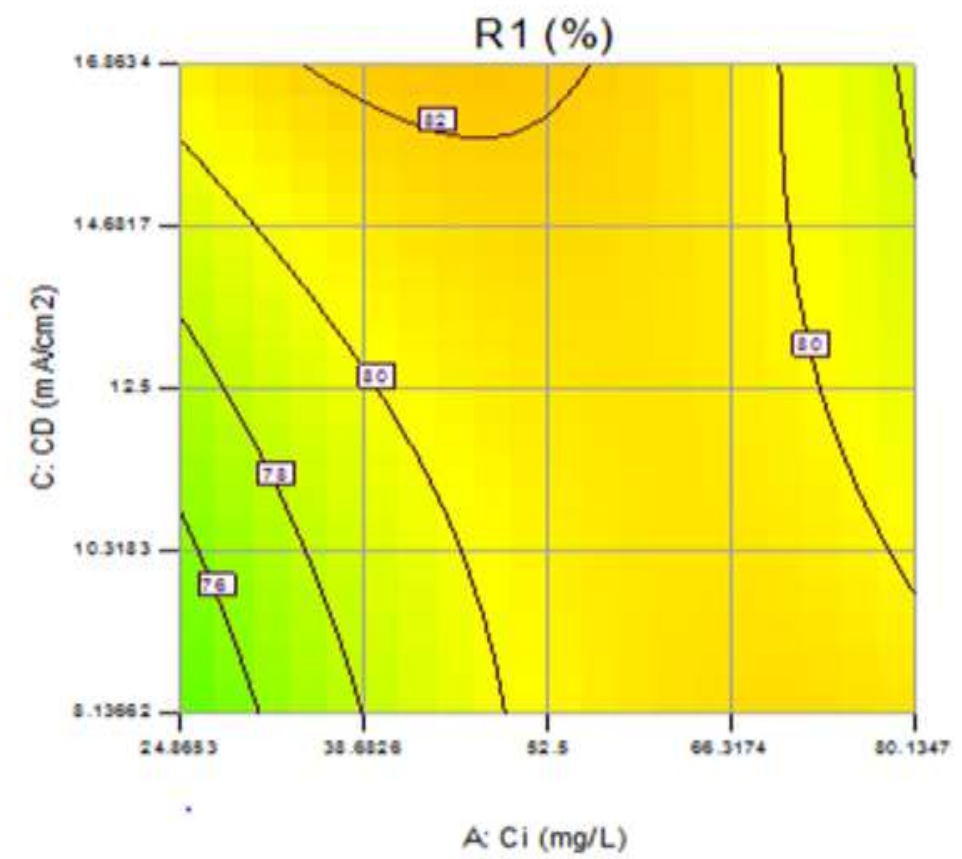

Fig. 6. Effect of current density on the efficiency of LVX removal 


\section{Effect of reaction time}

The time of electrolysis (t) affects the efficiency of the treatment in the electrochemical processes (11). The time of electrolysis determines the production rate of $\mathrm{Fe}^{3+}$ or $\mathrm{Fe}^{2+}$ ions from iron electrodes (11). To study the effect of reaction time on the removal efficiency of LVX, the EC process was conducted using different periods from 5 to $60 \mathrm{~min}$. As shown in Fig.7, the efficiency of LVX removal was increased from $70 \%$ to $80 \%$ by increasing the time of electrolysis from 16.5 to $48.5 \mathrm{~min}$ at the center point of important working parameters mentioned, including $42.79 \mathrm{mg} . \mathrm{L}^{-1} \mathrm{LVX}$ concentration,
$3.836 \mathrm{pH}$ and $16.27 \mathrm{~mA} . \mathrm{cm}^{-2}$ current density. Based on Faraday's law (Eq. 6), by an increase in the electrolysis time and current density, the rate of anode dissolution is rise that will raise $\mathrm{Fe}^{2+}$ dose produced from anode causing a more amount of precipitate to remove contaminants:

$$
\mathbf{E L C}=\frac{\mathrm{ItM}}{\mathbf{z F}}
$$

Where ELC, z, F, I, t, and M are the amount of electrode consumption $(\mathrm{g})$, the electron number, Faraday's constant $(96,485 \mathrm{C} / \mathrm{mol})$, the current in (amp), the reaction time in (sec), and the molecular weight of the electrode used (g/mol), respectively(35).

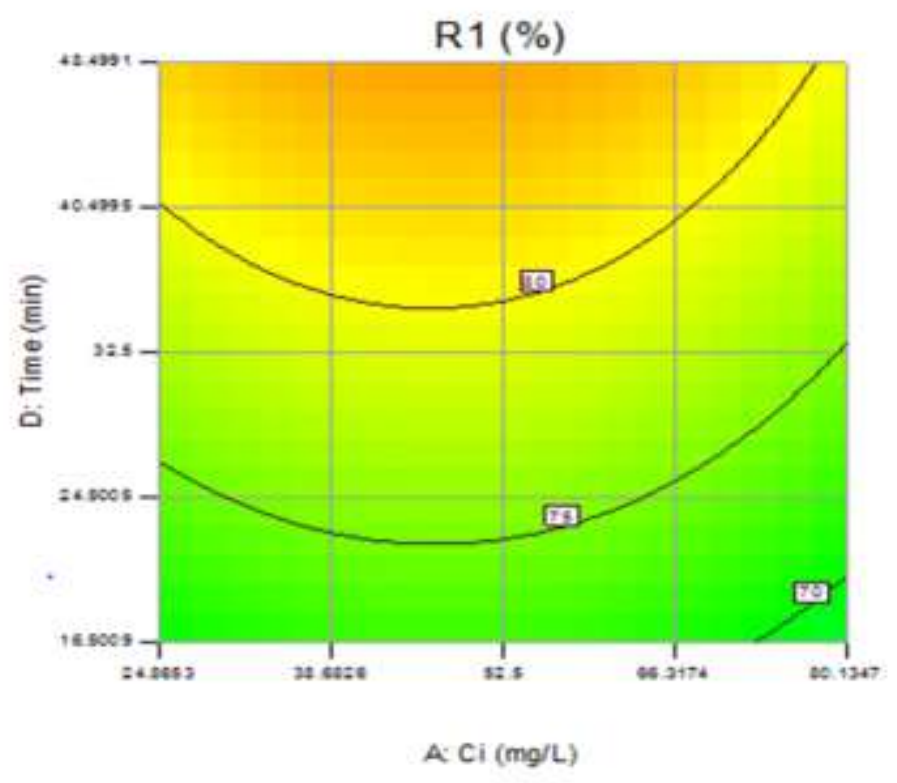

Fig. 7. Effect of electrolysis time on the efficiency of LVX removal

\section{Kinetics and isotherms}

The contaminant is usually adsorbed at the flocs surface that electrochemically produced, after two sequential separate processes: (i) the metal flocs are generated through the electrochemical process; (ii) followed by a process of physic-chemical, namely adsorption on the flocs surface. The pollutant removal is comparable to traditional adsorption except for the coagulants generation. It can be possible to estimate the electrode consumption according to the law of Faraday and the flocs amount produced which can be stoichiometrically evaluated. The iron flocs are present in the solution to remove the contaminants formed by way of adsorption mechanism. From this, the removal of pollutants can be modeled such that the adsorption phenomena and adsorbed pollutant amount estimates according to (Eq. 7).

$$
\mathbf{q}_{\mathbf{t}}=\frac{\left(\mathbf{C}_{\mathbf{o}}-\mathbf{C}_{\mathrm{t}}\right) \mathbf{V}}{\mathbf{M}}
$$

Where:

$\mathrm{q}_{\mathrm{t}}$ is the amount of levofloxacin (LVX) adsorbed per gram of medium $(\mathrm{mg} / \mathrm{g}), \mathrm{C}_{\mathrm{o}}$ is the initial concentration of $\operatorname{LVX}(\mathrm{mg} / \mathrm{l}), \mathrm{C}_{\mathrm{t}}$ is the concentration at any time of $\mathrm{LVX}(\mathrm{mg} / \mathrm{l})$, $\mathrm{M}$ is the weight of electrode dissolution $(\mathrm{g}), \mathrm{V}$ is the volume of solution (L). To study the mechanisms of the LVX adsorption process, the obtained experimental results were fitted to Freundlich, Langmuir, Sips, Temkin and Toth isotherm(10).

Kinetic modeling: The study of adsorption kinetics is significant in order to give valuable importance to the reaction pathway and the suitable absorption mechanism. The 
adsorption mechanism is depends on the physical and chemical characteristics of adsorption in addition to the process of the mass transfer. The LVX absorption dynamics on iron hydroxide flocs at the optimum conditions were investigated with respect to various initial LVX concentrations, by means of kinetic models: first order models, second order models, and pseudo first order models. The parameters of kinetic models were illustrated and calculated in Table 4 . Regression correlation coefficient values $\left(\mathrm{R}^{2}\right)$ concluded that LVX adsorption followed the second order kinetic model.

Table 4. Kinetic parameters to remove the LVX in optimum conditions for the EC process

\begin{tabular}{|c|c|c|c|c|c|}
\hline \multirow{3}{*}{$\begin{array}{c}\text { Model } \\
\text { First-order } \\
\text { kinetics }\end{array}$} & Equation & \multicolumn{2}{|c|}{ Parameter } & \multicolumn{2}{|r|}{ Reference } \\
\hline & $\mathbf{C}_{(\mathrm{t})}=\mathrm{C}_{\mathrm{o}} \mathbf{e}^{-\mathrm{K}_{1} \mathrm{t}}$ & $\operatorname{Co}(\mathrm{mg} / \mathrm{L})$ & $K_{1}\left(\min ^{-1}\right)$ & $\mathbf{R}^{2}$ & $(27)$ \\
\hline & & 5 & 0.032 & 0.045 & \\
\hline & & 10 & 0.05 & 0.245 & \\
\hline & & 20 & 0.053 & 0.23 & \\
\hline & & 30 & 0.045 & 0.292 & \\
\hline & & 50 & $\mathbf{0 . 0 3 2}$ & 0.725 & \\
\hline Second- & $\frac{1}{c}=\frac{1}{c}+k_{2} t$ & $\mathrm{Co}(\mathrm{mg} / \mathrm{L})$ & $K^{2}\left((\mathrm{mg} / \mathrm{L})^{-1} \cdot \min ^{-1}\right)$ & $\mathbf{R}^{2}$ & (27) \\
\hline order & $\mathrm{C}_{(\mathrm{t})} \quad \mathrm{C}_{\mathrm{o}}$ & 5 & 0.0095 & 0.873 & \\
\hline kinetics & & 10 & 0.015 & 0.985 & \\
\hline & & 20 & 0.008 & 0.985 & \\
\hline & & 30 & 0.0037 & 0.977 & \\
\hline & & 50 & 0.0013 & 0.884 & \\
\hline Pseudo-first- & $\mathbf{C}_{(\mathbf{t})}=\mathbf{C}_{\mathbf{e}}+$ & $\operatorname{Co}(\mathrm{mg} / \mathrm{L})$ & $K_{\text {app }}\left(\min ^{-1}\right)$ & $\mathbf{R}^{2}$ & (27) \\
\hline order & $\left(C_{o}-C_{e}\right) e^{-K_{a p p} t}$ & 5 & 0.098 & 0.868 & \\
\hline kinetics & (10) & 10 & 0.1 & 0.707 & \\
\hline & & 20 & 0.107 & 0.754 & \\
\hline & & 30 & 0.095 & 0.774 & \\
\hline & & 50 & 0.092 & 0.874 & \\
\hline
\end{tabular}

$K_{1}$ is the constant of first order kinetics $\left(\mathrm{min}^{-1}\right), K_{2}$ is the constant of second order kinetics $\left((\mathrm{mg} / \mathrm{L})^{-1}, \min ^{-1}\right), k_{\text {app }}$ is the apparent pseudo first-order rate constant $\left(\mathrm{min}^{-1}\right), \mathbf{R}^{2}$ is the correlation coefficient.

\section{Isotherm modeling}

During the EC process, the iron hydroxide flocs as the adsorbent were formed. The investigated of the absorption of pollutants on a surface of the iron hydroxides produced using five adsorption isotherm namely Langmuir, Freundlich, Sips, Temkin, and Toth models. Isotherm of adsorption can be employed to assess the adsorption capacity of adsorbent and obtain an insight into the response of adsorbent and adsorbate. The model with the best suitable correlation to the equilibrium curve can provide valuable information about the mechanism of adsorption. The adsorption experiments were conducted at five various initial LVX concentrations of $5,10,20,30$ and $50 \mathrm{mg} / \mathrm{L}$ in optimal conditions and the equilibrium were obtained. The obtained experimental results can be seen in Fig. 8.

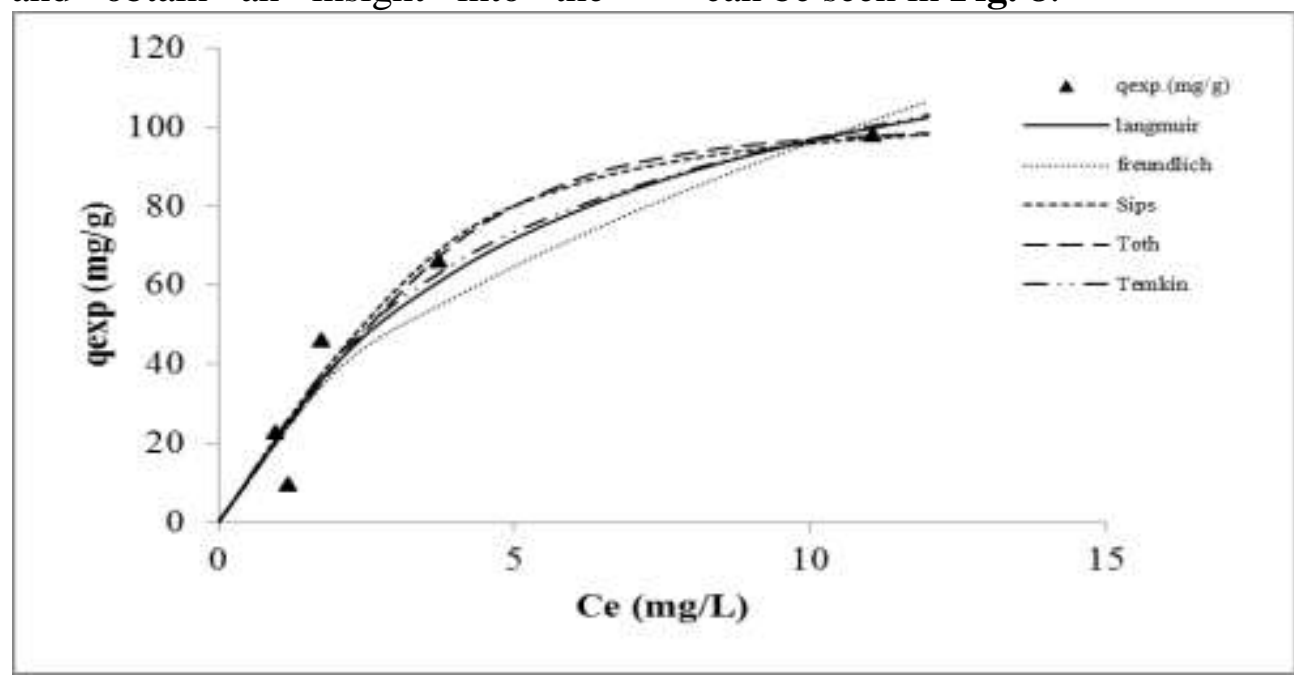

Fig. 8. Isothermal fits for EC removal of Levofloxacin: Freundlich, Langmuir, Toth, Temkin and Sips isotherm $\left(\mathrm{Ce}(\mathrm{mg} / \mathrm{L})\right.$ and $q_{\exp }(\mathrm{mg} / \mathrm{g})$ is the equilibrium concentration of $\mathrm{LVX}$ and equilibrium adsorption capacity, respectively.) 
The correlation coefficient $\left(\mathrm{R}^{2}\right)$ and the calculated and illustrated in Table 5. constants related to the isotherms were

Table 5. The calculations of Adsorption isotherms for the removal of Levofloxacin in an optimized electrocoagulation process conditions

\begin{tabular}{|c|c|c|c|c|c|}
\hline \multirow{2}{*}{\begin{tabular}{|c|} 
Model \\
Freundlich
\end{tabular}} & \multicolumn{2}{|c|}{ Equation } & \multicolumn{2}{|l|}{ Parameters } & Reference \\
\hline & $q_{e}=K_{f} C_{e}^{1 / n}$ & (11) & $\mathrm{K}_{\mathrm{f}}(\mathrm{mg} / \mathrm{g})(\mathrm{mg} / \mathrm{l}) 1 / \mathrm{nf}$ & 25.84 & \multirow[b]{2}{*}{ (24) } \\
\hline & & & n & 1.754 & \\
\hline \multirow{3}{*}{ Langmuir } & \multirow{4}{*}{$q_{e}=\frac{q_{m} b C_{e}}{1+b C_{e}}$} & \multirow{4}{*}{ (12) } & $\mathbf{R}^{2}$ & 0.873 & \multirow{4}{*}{ (24) } \\
\hline & & & $\mathbf{q}_{\max }(\mathrm{mg} / \mathrm{g})$ & 147.91 & \\
\hline & & & b (l/mg) & 0.188 & \\
\hline \multirow{4}{*}{ Sips } & & & $\mathbf{R}^{2}$ & 0.913 & \\
\hline & \multirow{3}{*}{$q_{e}=\frac{k_{s} C_{e} \beta_{s}}{1+a_{s} C^{\beta_{s}}}$} & \multirow[t]{4}{*}{ (13) } & $\mathbf{K}_{\mathrm{s}}$ & 21.79 & \multirow{3}{*}{ (24) } \\
\hline & & & $\boldsymbol{\beta}_{\mathrm{s}}$ & 1.691 & \\
\hline & & & $\mathbf{a}_{\mathrm{s}}$ & 0.207 & \\
\hline \multirow{3}{*}{ Toth } & \multirow{3}{*}{$\mathbf{q}_{\mathrm{e}}=\frac{\mathbf{q}_{\mathrm{m}} \mathrm{C}_{\mathrm{e}}}{\left(\mathbf{b}+\mathrm{C}_{\mathrm{e}}^{\mathrm{m}}\right)^{\frac{1}{\mathrm{~m}}}}$} & & $\mathbf{R}^{2}$ & 0.937 & \multirow{3}{*}{ (28) } \\
\hline & & \multirow[t]{2}{*}{ (14) } & $\mathbf{q}_{\max }(\mathrm{mg} / \mathrm{g})$ & 101.1 & \\
\hline & & & b & 90.7 & \\
\hline \multirow{5}{*}{ Temkin } & & & $\mathbf{m}$ & 2.838 & \multirow{5}{*}{ (26) } \\
\hline & & & & 0.93 & \\
\hline & \multirow{2}{*}{\multicolumn{2}{|c|}{$q_{e}=\underset{(15)}{B \ln A_{T}}+B \ln C_{e}$}} & B (J/mol) & 34.107 & \\
\hline & & & $A_{T}(L / g)$ & 1.71 & \\
\hline & $\mathbf{B}=\frac{\mathbf{R T}}{\mathbf{b}}$ & (16) & $\mathbf{R}^{2}$ & 0.931 & \\
\hline
\end{tabular}

It seems from the table 5, that all these adsorption isotherm models can describe effectively experimental results due to their correlation coefficient $\left(\mathrm{R}^{2}\right)$ more than 0.873 . However, depending on the greatest correlation coefficient values which revealed that the adsorption levofloxacin by the metal hydroxide flocs agrees well Sips isotherm model with a correlation coefficient of 0.937 . Sips isotherm shows that both homogenous and heterogeneous adsorption occurs.

\section{CONCLUSION}

The present work was an effective step to enhance our knowledge about the removal of LVX using the EC technique with stainless steel electrodes. The purpose of this study was to investigate the influence of independent parameters on the removal efficiency of LVX from the aqueous solution using electrocoagulation technique. The experiential design was executed depending on CCD with response surface methodology. Response surface methodology was employed to evaluate the effect of independent variables on the efficiency of LVX removal and achieve their optimum condition. The obtained experimental results indicated that response surface methodology was an appropriate means to improve the operating conditions of the electrocoagulation process to remove the LVX. ANOVA revealed a high correlation coefficient $\left(\mathrm{R}^{2}\right)$ of 0.9521 , which indicates an acceptable modification of the model of second-order regression with the obtained results. The electrocoagulation process was achieved successfully with the efficiency of LVX removal of $82.5 \%$ under the optimum experimental conditions of the current density of $16.27 \mathrm{~mA} . \mathrm{cm}^{-2}$, inter-electrode distance 1.5 $\mathrm{cm}, \mathrm{pH}$ value 3.836 , reaction time $42 \mathrm{~min}$, and initial LVX concentration of $42.79 \mathrm{mg} . \mathrm{L}^{-1}$ and $\mathrm{NaCI}$ concentration of $500 \mathrm{mg} . \mathrm{L}^{-1}$. The results of the kinetic study showed that the secondorder kinetic model was in good agreement with the experimental results and suggested that the mechanism of chemisorption controlled the LVX adsorption. The experimental results indicated that the adsorption of LVX on iron hydroxide flocs follows Sips isotherm with the value of the correlation coefficient $\left(\mathrm{R}^{2}\right)$ of 0.937 . Sips isotherm shows that both homogenous and heterogeneous adsorption occurs. Finally, the electrocoagulation process used in this work provided a sensitive, fast and dependable technique for LVX removal.

\section{REFERENCES}

1. Abbas, A.A.A.,and F.M. Hassan, 2018. Water quality assessment of Euphrates river in Qadisiyah province (Diwaniyah river), Iraqi J. Agric. Sci 49(2): 251-261 
2. Abed, K. M., 2014. Kinetic of alkaloids extraction from plant by batch pertraction in rotating discs contactor. Iraqi J. of Chem. and Petr. Eng., 15(2): 75-84

3. Abdullah, S.A., A.H.J. Abdullah, and M.A. Ankush, 2019. Assessment of water quality in the euphertes river, southern iraq. Iraqi J. Agric. Sci. 50: 312-319

4. Ahmadzadeh, S., A. Asadipour, M. Pournamdari, B. Behnam, H.R. Rahimi, and M. Dolatabadi, 2017. Removal of ciprofloxacin from hospital wastewater using electrocoagulation technique by aluminum electrode: Optimization and modelling through response surface methodology. Process Saf. Environ. Prot. 109: 538-547

5. Aoda, M.I., and M.A. Fattah, 2011. The interactive effects of water magnetic treatment and deficit irrigation on plant productivity and water use efficiency of corn (Zea mays L.). Iraqi J. Agric. Sci. 42: 164-179

6. Avisar, D., O. Primor, I. Gozlan, and H. Mamane, 2010. Sorption of sulfonamides and tetracyclines to montmorillonite clay. Water, Air, Soil Pollut. 209, 439-450

7. Barışç1, S., and O.Turkay, 2015. Optimization and modelling using the response surface methodology (RSM) for ciprofloxacin removal by electrocoagulation. Water Sci. Technol. 73: 1673-1679

8. Bautitz, I.R., and R.F.P. Nogueira, 2007. Degradation of tetracycline by photo-Fenton process Solar irradiation and matrix effects. J. Photochem. Photobiol. A Chem. 187: 33-39

9. Chen, W.-R., and C.-H. Huang, 2010. Adsorption and transformation of tetracycline antibiotics with aluminum oxide. Chemosphere 79: 779-785

10. Chithra, K., and N. Balasubramanian, 2010. Modeling electrocoagulation through adsorption kinetics. J. Model. Simul. Syst. 1: 124-130

11. Daneshvar, N, A.R. Khataee, and N. Djafarzadeh, 2006. The use of artificial neural networks (ANN) for modeling of decolorization of textile dye solution containing CI Basic Yellow 28 by electrocoagulation process. J. Hazard. Mater. 137: 1788-1795

12. Daneshvar, N., A. Oladegaragoze, and N. Djafarzadeh, 2006. Decolorization of basic dye solutions by electrocoagulation: An investigation of the effect of operational parameters. J. Hazard. Mater. 129: 116-122.

13. Daneshvar, N., H.A. Sorkhabi, and M.B. Kasiri, 2004. Decolorization of dye solution containing acid red 14 by electrocoagulation with a comparative investigation of different electrode connections. J. Hazard. Mater. 112: 55-62

14. de Lima Perini, J.A., B.C. e Silva, A.L. Tonetti, and R.F.P. Nogueira, 2017. PhotoFenton degradation of the pharmaceuticals ciprofloxacin and fluoxetine after anaerobic pre-treatment of hospital effluent. Environ. Sci. Pollut. Res. 24: 6233-6240

15. Epold, I., M. Trapido, and N. Dulova, 2015. Degradation of levofloxacin in aqueous solutions by Fenton, ferrous ion-activated persulfate and combined Fenton/persulfate systems. Chem. Eng. J. 279: 452-462

16. Hassan, D.F., A.A. Jafaar, and R.J. Mohamm, 2019. Effect of irrigation water salinity and tillage systems on some physical soil properties. Iraqi J. Agric. Sci. 50: 42-47

17. Jin, T., W. Yuan, Y. Xue, H. Wei, C. Zhang, and K.Li, 2017. Co-modified MCM41 as an effective adsorbent for levofloxacin removal from aqueous solution: optimization of process parameters, isotherm, and thermodynamic studies. Environ. Sci. Pollut. Res. 24: 5238-5248

18. Kaur, A., and S.K. Kansal, 2016. Bi2WO6 nanocuboids: an efficient visible light active photocatalyst for the degradation of levofloxacin drug in aqueous phase. Chem. Eng. J. 302: 194-203

19. Khan, M.H., H. Bae, and J.-Y. Jung, 2010. Tetracycline degradation by ozonation in the aqueous phase: proposed degradation intermediates and pathway. J. Hazard. Mater. 181: 659-665

20. Khandegar, V., and A.K. Saroha, 2013. Electrocoagulation for the treatment of textile industry effluent - A review. J. Environ. Manage. 128: 949-963.

21. Kümmerer, K., 2009. Antibiotics in the aquatic environment-a review-part I. Chemosphere 75: 417-434

22. Liu, Y., X. Gan, B. Zhou, B. Xiong, Li, J., C. Dong, J. Bai, and W. Cai, 2009. Photoelectrocatalytic degradation of tetracycline by highly effective $\mathrm{TiO} 2$ nanopore 
arrays electrode. J. Hazard. Mater. 171: 678683

23. Merzouk, B., B. Gourich, A. Sekki, K. Madani, C. Vial,and M. Barkaoui, 2009. Studies on the decolorization of textile dye wastewater by continuous electrocoagulation process. Chem. Eng. J. 149: 207-214

24. Mohammed-Ridha, M.J., and M.Y. AbdulAhad, 2014. Adsorption of levofloxacine antibacterial from contaminated water by nonconventional low cost natural waste materials. J. Eng. 20: 88-104

25. Moreno C, H.A., D.L. Cocke, J.A.G. Gomes, P. Morkovsky, J.R. Parga, E. Peterson, and C. Garcia, 2009. Electrochemical reactions for electrocoagulation using iron electrodes. Ind. Eng. Chem. Res. 48: 2275-2282

26. Naji, L.A., S.H. Jassam, M.J. Yaseen, A.A.H. Faisal, and N. Al-Ansari, 2019. Modification of Langmuir model for simulating initial $\mathrm{pH}$ and temperature effects on sorption process. Sep. Sci. Technol. 0: 1-8.

27. Nariyan, E., A. Aghababaei,and M. Sillanpää, 2017. Removal of pharmaceutical from water with an electrocoagulation process; effect of various parameters and studies of isotherm and kinetic. Sep. Purif. Technol. 188: 266-281

28. Ouaissa, Y.A., M. Chabani, A. Amrane, and A. Bensmaili, 2014. Removal of tetracycline by electrocoagulation: Kinetic and isotherm modeling through adsorption. J. Environ. Chem. Eng. 2: 177-184.

29. Rahmani, A.R., D. Nematollahi, M.R. Samarghandi, M.T. Samadi, and G. Azarian, 2018. A combined advanced oxidation process: Electrooxidation-ozonation for antibiotic ciprofloxacin removal from aqueous solution. J. Electroanal. Chem. 808: 82-89

30. Reyes, C., J. Fernandez, J. Freer, M.A. Mondaca, C. Zaror, S. Malato,and H.D. Mansilla, 2006. Degradation and inactivation of tetracycline by $\mathrm{TiO} 2$ photocatalysis. J. Photochem. Photobiol. A Chem. 184: 141-146 31. Tanis, E., K. Hanna, and E. Emmanuel, 2008. Experimental and modeling studies of sorption of tetracycline onto iron oxidescoated quartz. Colloids Surfaces A Physicochem. Eng. Asp. 327: 57-63

32. Vasudevan, S., J. Jayaraj, J. Lakshmi, and G. Sozhan, 2009. Removal of iron from drinking water by electrocoagulation: adsorption and kinetics studies. Korean J. Chem. Eng. 26: 1058-1064

33. Wang, Y.-J., D.-A. Jia, R.-J. Sun, H.-W. Zhu, and D.-M. Zhou, 2008. Adsorption and cosorption of tetracycline and copper (II) on montmorillonite as affected by solution $\mathrm{pH}$. Environ. Sci. Technol. 42: 3254-3259

34. Wei, H., D. Hu, J. Su, and K. Li, 2015. Intensification of levofloxacin sonodegradation in a $\mathrm{US} / \mathrm{H}_{2} \mathrm{O}_{2}$ system with $\mathrm{Fe} 3 \mathrm{O} 4$ magnetic nanoparticles. Chinese J. Chem. Eng. 23: 296-302

35. Yazdanbakhsh, A.R., M.R. Massoudinegad, S. Eliasi, and A.S. Mohammadi, 2015. The influence of operational parameters on reduce of azithromyin COD from wastewater using the peroxi-electrocoagulation process. J. Water Process Eng. 6: 51-57

36. Yoosefian, M., S. Ahmadzadeh, M. Aghasi, and M. Dolatabadi, 2017. Optimization of electrocoagulation process for efficient removal of ciprofloxacin antibiotic using iron electrode; kinetic and isotherm studies of adsorption. J. Mol. Liq. 225: 544553

37. Zaidi, S., T. Chaabane, V. Sivasankar, A. Darchen, R. Maachi, and T.A.M. Msagati, 2015. Electro-coagulation coupled electroflotation process: Feasible choice in doxycycline removal from pharmaceutical effluents. Arab. J. Chem.12: 2798-2809

38. Zaidi, S., T. Chaabane, V. Sivasankar, A. Darchen, R. Maachi, T.A.M. Msagati, and M.Prabhakaran, 2016. Performance efficiency of electro-coagulation coupled electroflotation process (EC-EF) versus adsorption process in doxycycline removal from aqueous solutions. Process Saf. Environ. Prot. 102: 450-461. 